\title{
EVALUASI PEMANFAATAN KOLEKSI DENGAN MENGGUNAKAN ANALISIS SITASI (Studi Analisis Sitasi Skripsi Mahasiswa di Perpustakaan Pusat IAIN Sunan Kalijaga Yogyakarta)
}

\author{
Oleh Sri Rohyanti Zulaikha*); Agus Dwiyanto**) Tri Septiyantono ***)
}

\section{ABSTRACT}

The objective of the study is to evaluate the use of collection by using citation analysis to know the pattern of use of literature by the students of IAIN Sunan Kalijaga Yogyakarta in writing their theses based on kinds, languages, and literature which were dominantly quoted, to know the use of collection and the collection availability.

The used methodology in this research were descriptive statistical research which took all of IAIN Sunan Kalijaga students' theses collections in 2000 comprising 445 theses. Then, their bibliographies were taken and resulted in 11.058 quotes. Those theses represented five faculties. The analysis was presented in the form of data tabulation, percentage and frequency tables.

The results showed that the pattern of use of literature in the theses based on the kinds of quoted literatures were books, they were 10133 times quoted (92\%); magazines, journals and newspapers were 925 times (8\%). Based on the languages, the compositions were Indonesian 8420 quoted (77\%); Arabic 2263 (20\%); English 375 (3\%). Based on the titles, the results were that the students quoted the titles evenly and vary. It started from quoted frequencies for $196(1.8 \%)$, $112(1.0 \%), 81(0.7 \%)$, to the frequency of once quotation.

The use level of collection by the students was high. It was based on the result of questionnaires which were based on the literature titles resulted in the evenly spread collection. The percentages vary. They were $1.8 \%, 1.0 \%, 0.7 \%$, and $0.6 \%$ to $0.0 \%$. The students complete their theses used the collection in the library of IAIN Sunan Kalijaga. Based on the collection availability, the conclusion was that the library provided $99.98 \%$ of the needed collection.

The variety of collection has to be increased in the future and in order to make the use of journal to be more effective, to develop Arabic language collection. Therefore, it needs to develop Arabic language collection. Emphasizing the ability in reading foreign literature, mainly in Arabic could increase the use of Arabic and English collections by the library user. It was suggested that to get more accurate view, this data has to be developed in the following studies, such as by comparing the literature circulation data. This study is expected to be a starting study for the next studies on the productivity of the writer and the old fashioned literature because it still needs subsequent study for the sake of the library collection development.

Keywords: Library; citation analysis ; collection use study ; collection availability

*). Library Staff, Sunan Kalijaga Islamic Institute Yogyakarta

**) Teaching Staff of the Faculty of Social and Political Sciences, Gadjah Mada University

***) Librarian, Gadjah Mada University Yogyakarta

\begin{abstract}
ABSTRAK
Tujuan penelitian ini adalah untuk mengevaluasi pemanfaatan koleksi melalui analisis sitasi untuk mengetahui pola pemanfaatan lliteratur oleh mahasiswa IAIN Sunan Kalijaga dalam penyusunan tugas akhir dilihat dari jenis literature, bahasa, dan judul yang sering dikutip agar diketahui pemanfaatan dan ketersediaan koleksi.

Penelitian menunjukkan literatur yang paling sering digunakan berupa buku berbahasa Indonesia, sedangkan judul yang dikutip bervariasi. Juga ditunjukkan bahwa pemanfaatan koleksi perpustakaan oleh mahasiswa relatif tinggi. Bahkan 99,98\% koleksi yang dibutuhkan tersedia di perpustakaan.
\end{abstract}

Kata Kunci: Perpustakaan; Analisis Sitasi; Pemanfaatan Koleksi; Ketersediaan Koleksi *). Staf Perpustakaan, IAIN Sunan Kalijaga Yogyakarta

**). Dosen Fakultas Ilmu Sosial dan Ilmu Politik Universitas Gadjah Mada Yogyakarta

***). Pustakawan Universitas Gadjah Mada Yogyakarta 


\section{PENDAHULUAN}

\section{Latar belakang}

Kecilnya jumlah koleksi suatu perpustakaan atau pusat-pusat informasi merupakan salah satu kendala bagi seseorang untuk memperoleh informasi . Seperti terungkap dalam Survai dan Kajian Perpustakaan Perguruan Tinggi : kajian pelayanan di 7 propinsi menyatakan bahwa dari seluruh jumlah responden sebanyak 527 responden yang menjawab tidak puas terhadap koleksi perpustakaan merupakan responden terbesar yaitu 3.324 responden $(60,14 \%)$, (Perpustakaan Nasional, 1992 : 16). Sedangkan pertanyaan mengenai faktor-faktor apa saja yang menghambat dalam pelayanan perpustakaan untuk mendapatkan informasi, sejumlah responden 2.031 (36,74\%) menjawab faktor koleksi perpustakaan. Sehingga hasil survai tersebut mengatakan bahwa koleksi merupakan faktor penghambat utama dalam keberhasilan pelayanan (Perpustakaan Nasional, 1992 : 21).

Koleksi perpustakaan universitas memang terasa kurang . Banyak perguruan tinggi yang tumbuh, tetapi prasarana dan sarananya kurang memadai, serta masih jauh dari kesesuaian dengan kebutuhan pemakai . Seperti dinyatakan oleh Chirgwin (1988), Gorman, (1991), dalam Magrill (1989) bahwa koleksi suatu perpustakaan hendaknya disesuaikan dengan kebutuhan pemakai perpustakaan dan mudah untuk diakses. Hal itu seharusnya kemudian mendorong perpustakaan untuk dapat memilih dan mengadakan koleksi yang sesuai dengan bidang dan jenis kebutuhan pemakai.Para pustakawanpun harus mampu mengetahui karakteristik yang dibutuhkan pemakai. Kecilnya jumlah koleksi dan ketidaksesuaian koleksi dengan kebutuhan pemakai menjadi kendala dalam pencarian literatur yang dibutuhkan.

Untuk mengetahui kebutuhan yang diinginkah oleh pemakai perpustakaan, diperlukan studi penelitian atau evaluasi terhadap suatu koleksi. Salah satu cara untuk mengevaluasi koleksi antara lain dengan menggunakan analisis sitasi/ citation analysis. Salah satunya seperti yang dikemukakan oleh University of Wyoming Libraries (1998: 8) dalam Collection Development bahwa analisis sitasi merupakan alat yang tepat untuk mengevaluasi keterpakaian koleksi di suatu perpustakaan.Karena merupakan metode yang sederhana dan dapat diangkat setiap saat. Teknik ini bertujuan untuk melihat berapa kali suatu sumber itu dikutip dalam penyusunan suatu karya ilmiah. Berkaitan dengan hal tersebut, tujuan dari penelitian ini adalah : untuk mengetahui bagaimana pola penggunaan literatur dalam penyusunan skripsi mahasiswa berdasarkan jenis, bahasa dan literatur yang dominan disitir, Juga untuk mengetahui seberapa jauh keterpakaian koleksi di UPT Perpustakaan IAIN Sunan Kalijaga Yogyakarta.

\section{LANDASAN TEORI}

\section{Evaluasi Koleksi Perpustakaan}

S.R. Ranganathan (1892-1972) dalam "Five laws of library science" antara lain mengatakan bahwa "every book its reader". Hal itu mengandung makna bahwa perpustakaan harus peduli akan ketersediaan dan aksesabilitas bahan pustaka. Oleh karenanya, perpustakaan harus berupaya memberikan informasi kepada pemakai tentang bahan pustaka yang potensial untuk digunakan dan secara tidak langsung mempunyai tanggungjawab mengevaluasi bahan pustaka (Kuronen, 1999 : 46). Mengevaluasi koleksi perpustakaan merupakan suatu kegiatan untuk mengetahui sejauh mana koleksi yang ada betul-betul memenuhi kebutuhan pemakai. Evaluasi koleksi merupakan proses yang terorganisir untuk menganalisis secara sistematis mengenai koleksi perpustakaan (info@dlapr.lib.az.us). Evaluasi koleksi pada dasarnya adalah bagian dari evaluasi perpustakaan. Pertanyaan yang dikemukakan pertama kali setiap evaluasi dan pengukuran perpustakaan selalu difokuskan pada apakah koleksi di perpustakaan sesuai dan mendukung tujuan perguruan tinngi 
atau tidak (Wedgeworth, 1993 : 548). Sejalan dengan apa yang sudah disebutkan sebelumnya, evaluasi koleksi merupakan fungsi yang esensial dalam manajemen pengembạgan koleksi.

Berkaitan dengan penelitian ini, teori-teori yang dikemukakan oleh Jenkins, Morgan, dan Magrill, kesemuanya menyatakan teori tentang evaluasi koleksi. Kemudian dalam penelitian ini, metode yang digunakan untuk mengukur evaluasi koleksi adalah metode yang dikemukakan oleh Magrill, dengan menggunakan analisis sitasi.

\section{Analisis Sitasi}

Analisis sitasi merupakan salah satu teknik bibliometrika. Bibliometrika adalah penerapan metode matematika dan statistika terhadap buku-buku dan bentukbentuk komunikasi tertulis lainnya untuk mengetahui proses komunikasi tertulis, dengan cara menghitung dan menganalisis berbagai faset komunikasi tertulis. Istilah sitasi /citation berarti: "sitiran, kutipan, sebutan" (Echols, 1975 : 114). Harrod's Librarians' Glossary (1995 : 133) dinyatakan bahwa sitasi merupakan rujukan pada teks atau bagian dari teks yang memperkenalkan dokumen yang diperoleh. Dengan kata lain bahwa sitasi adalah karya yang dirujuk atau digunakan sebagai bibliografi oleh sebuah artikel, buku atau sumber-sumber lain. Maka analisis sitasi merupakan kajian terhadap sejumlah sitiran atau rujukan yang terdapat dalam karya tulis ilmiah tertentu. Diungkapkan juga oleh Stephen P. Harter (1996 : 1) yang menulis artikel berjudul "The Impact of Electronic Journals on Scholarly communication : a Citation analysis" yang dimuat dalam The Public-Access computer System Review 7, no. 5, 1996 bahwa "citation analysis" adalah :

"a generic term for a set of well-known techniques that have a long history in bibliometric studies of scholarly communication. As artifacts of the scholarly communication process, citation can reveal formal communication pattern. And methods of citation analysis are unobtrusive and can be highly reliable".
Bahwa analisis sitasi merupakan teknik yang sudah populer dalam kajian bibliometri. Sebagai proses komunikasi, maka analisis sitasi dapat menghasilkan pola komunikasi formal dimana metode sitasi tersebut dapat diandalkan keakuratannya.

Terdapat beberapa alasan mengapa para ilmuwan dan peneliti selalu menyitir berbagai macam literatur dalam rangka penulisan karya tulis mereka antara lain sebagai alasan etika, pengakuan terhadap suatu prestasi dan membantu para pembaca dalam menemukan kembali informasi yang diinginkannya. Adapun . analisis sitasi yang akan dikaji dalam penelitian ini adalah menggunakan suatu rujukan atau sitiran yang dikumpulkan dari skripsi. University of Wyoming Libraries (1998:8) dalam “Collection assessment” menyatakan bahwa analisis sitasi merupakan alat yang tepat untuk mengevaluasi keterpakaian koleksi di suatu perpustakaan, dan merupakan metode yang sederhana yang dapat dilakukan setiap saat. Studi yang memanfaatkan analisis sitasi didasarkan atas asumsi bahwa bahan yang banyak dikutip atau disebut (dalam acuan catatan kaki, bibliografi, indeks dan abstrak) adalah bahan yang lebih sering digunakan dibandingkan bahan yang jarang atau tidak dikutip.

\section{METODE PENELITIAN}

Metode yang digunakan dalam penelitian ini adalah metode deskriptif yang bertujuan untuk melakukan analisis hanya sampai pada taraf deskriptif yaitu menganalisa dan menyajikan fakta secara sistematis sehingga mudah dipahami dan disimpulkan. Metode ini banyak digunakan dalam penelitian sosial karena kebanyakan ilmu sosial itu bersifat deskriptif(Nasution, 1982 : 32). Penelitian ini mengambil skripsi sebagai obyek yang akan dianalisis yaitu seluruh karya skripsi yang terdapat dalam database UPT Perpustakaan IAIN Sunan Kalijaga Yogyakarta tahun 2000. Populasi ini terdiri dari seluruh skripsi mahasiswa IAIN Sunan Kalijaga Yogyakarta tahun 2000 sebanyak 445 eks. yang terdiri dari 5 
fakultas dengan rincian sebagai berikut; skripsi mahasiswa Fakultas Adab sebanyak 60, Fakultas. Dakwah sebanyak 60, Fakultas. Syari'ah sebanyak 155, Fakultas. Tarbiyah 120, dan Fakultas.Ushuluddin sebanyak 50. Jumlah keseluruhan populasi adalah 445 skripsi. Metode pengumpulan data yang dipergunakan adalah metode riset kepustakaan/Library Research, dokumentasi, dan wawancara sebagai bahan check dan recheck. Setelah kegiatan pengumpulan data selesai,kemudian peneliti melakukan kegiatan analisis data.

\section{PEMBAHASAN}

\section{Hasil Analisis Pola Penggunaan literatur}

Dari analisis 11058 sitasi pada skripsi tahun 2000 di UPT Perpustakaan IAIN Sunan Kalijaga Yogyakarta didapatkan hasil bahwa buku adalah jenis literatur yang paling banyak disitir, kemudian majalah, jurnal dll. Buku merupakan jenis literatur yang paling banyak dimanfaatkan oleh mahasiswa dalam penyusunan skripsi mereka mencapai 10133 kali disitir, dengan prosentase sebanyak $92 \%$. Kemudian disusul jenis koleksi majalah (jurnal, surat kabar), mendapatkan sebanyak 925 disitir, dengan prosentase $8 \%$.

Kecenderungan mahasiswa enggan untuk menggunakan jurnal antara lain adalah karena terbitan berkala tersebut merupakan terbitan lama. Disamping itu juga kebanyakan mahasiswa tidak tahu koleksi jurnal di UPT Perpustakaan Kecenderungan yang lain karena jurnal tidak relevan dengan topik bahasan skripsi yang sedang disusun.

Dari hasil analisis 11058 sitasi seluruh skripsi tahun 2000 di UPT Perpustakaan IAIN Sunan Kalijaga Yogyakarta didapatkan hasil bahwa mahasiswa IAIN Sunan Kalijaga dalam penyusunan skripsi banyak menggunakan sumber rujukan yang berbahasa Indonesia, sebanyak 8420 sitiran atau sebesar $77 \%$, kemudian bahasa Arab mencapai 2263 sitiran atau sebesar $20 \%$, dan bahasa Inggris sebanyak 375 sitiran atau sebesar $3 \%$. Dari berbagai pendapat pemakai perpustakaan yang dapat digunakan sebagai check dan recheck, maka kecenderungan memilih buku dari pada jurnal dan majalah. Sebab mahasiswa lebih mudah mendapatkan buku sebagai bahan rujukannya daripada majalah, karena di setiap perpustakaan, buku selalu mendapatkan prioritas pertama dalam pengadaaannya apabila dibandingkan dengan majalah dan jurnal, yang lebih sulit untuk mendapatkannya ; Dari segi pendanaannya, perpustakaan juga terlalu berat untuk melanggan suatu majalah dan jurnal apalagi yang terbitan luar negeri. Keterbatasan-keterbatasan itu kemungkinan juga mendukung kurang minatnya mahasiswa menggunakan majalah dan jurnal sebagai bahan rujukan dalam penyusunan skripsi. Sebab mahasiswa tidak menemukan topik yang sesuai dengan pembahasan skripsi pada jenis literatur majalah, jurnal dan surat kabar, sehingga mahasiswa lebih memilih literatur buku ; Sulitnya mencari topik yang sesuai dengan bahasannya di jurnal dan majalah ; Karena perbedaan kebutuhan informasi di bidang sosial dan eksakta. Mahasiswa IAIN Sunan kalijaga Yogyakarta yang dalam hal ini berkecimpung dalam bidang sosial, lebih membutuhkan buku daripada daripada majalah ataupun jurnal. Hal ini juga didukung dengan pendapat Garvey (1979:269) dalam bukunya yang berjudul "Communication : the essence of science" yang menyatakan bahwa terdapat perbedaan kebutuhan informasi antara ilmuwan bidang sosial dan ilmuwan bidang eksakta. Bagi kalangan ilmuwan di bidang sosial, buku cenderung lebih banyak digunakan dan dimanfaatkan apabila dibanding dengan jenis-jenis literatur lainnya. Kebalikannya, majalah, jurnal, dan surat kabar lebih banyak digunakan dan dimanfaatkan oleh mahasiswa bidang eksakta. Salah satu alasan mengapa majalah lebih banyak disitir di bidang eksakta, disebabkan karena majalah memuat informasi yang lebih mutakhir yang sangat dibutuhkan oleh para peneliti guna mengikuti perkembangan ilmu pengetahuan dan teknologi.

Salah satu alasan mengapa mahasiswa IAIN Sunan kalijaga Yogyakarta banyak menggunakan bahasa Indonesia 
apabila dibanding bahasa Arab, bahasa Inggris atau dengan kata lain mengapa bahasa Indonesia menduduki peringkat pertama 8420 sitiran ( $77 \%$ ), disebabkan oleh beberapa faktor antara lain sesuai dengan pendapat para pemakai perpustakaan : Karena literatur yang berbahasa Indonesia merupakan literatur yang langsung bisa dipahami artinya oleh mahasiswa dan tidak perlu menterjemahkan lagi (wawancara dengan Tanti Nur Fauziyah, Fakultas Dakwah KPI, di UPT Perpustakaan) ; Memang sengaja menghindar menggunakan bahasa asing karena tidak bisa (wawancara dengan Nizar Nur Fakultas Syari'ah PM, di UPT Perpustakaan); Sumber rujukan yang digunakan adalah yang berbahasa Indonesia (sesuai wawancara dengan Ahmad Syafi'udin Fakultas Ushuluddin, PA, di UPT Perpustakaan yang mengatakan bahwa "saya memang menggunakan rujukan berbahasa Indonesia karena penelitian saya yang berjudul Radikalisasi Agama Dalam Konstalasi Politik Orde Baru, lebih mengarah kepada fenomenologi tahun 1984 dalam konteks Indonesia"). Kemudian peringkat kedua diduduki oleh literatur yang berbahasa Arab. Bahasa Arab menempati peringkat kedua disitir sebanyak 2263 (20\%) artinya mahasiswa menempatkan bahasa Arab sebagai peringkat ke dua setelah bahasa Indonesia. Perbandingan dalam pemakaian bahasa pada hasil penelitian ini begitu menonjol antara 8420 sitiran (77\%) untuk literatur berbahasa Indonesia dengan 2263 sitiran (20\%) untuk literatur berbahasa Arab.

Faktor penyebab koleksi bahasa Arab lebih jarang digunakan dalam penyusunan skripsi antara lain karena (1) memang literatur yang berbahasa Arablah yang digunakan untuk penyusunan skripsi, karena sebagai institusi Islam maka literatur berbahasa Arab tidak dapat ditinggalkan (2) jumlah literatur berbahasa Arab lebih sedikit apabila dibanding dengan literatur berbahasa Indonesia. (seperti diutarakan oleh Ahmad Syafi'udin, di UPT Perpustakaan) dan memang UPT Perpustakaan menyediakan literatur berbahasa Arab sebanyak $14 \%$ dari segi judul, $16 \%$ dari segi eksemplar sementara bahasa Indonesia $60 \%$ judul dan $66 \%$ eksemplar (3) sistem pendidikan yang dilaksanakan tidak "Arabic language literate".

Sebagaimana diketahui bahwa sistem pendidikan di IAIN Sunan Kalijaga tidak menghasilkan mahasiswa yang cakap dalam membaca literatur berbahasa Arab. Sehingga ada keengganan untuk menggunakan literatur berbahasa Arab, seperti diutarakan oleh Nizar Nur bahwa "saya selalu menghindar dengan bahasa asing apapun termasuk bahasa Arab, karena tidak bisa dan tidak ada kemajuan walaupun sudah diajarkan oleh dosen bahasa asing. Solusi yang kemungkinan bisa dilakukan untuk lebih meningkatkan mahasiswa dalam 'melek bahasa Arab' adalah dengan memberlakukan matrikulasi Bahasa Arab untuk mahasiswa baru.

Kemudian peringkat terakhir adalah literatur yang berbahasa Inggris sebanyak 375 (3\%). Literatur berbahasa Inggris ini jarang digunakan oleh mahasiswa disebabkan : Mereka memang tidak memerlukan literatur yang berbahasa Inggris ; Karena harus menerjemahkan lagi ke dalam bahasa Indonesia yang memakan waktu dan biaya ; Mencari literatur berbahasa Inggris lebih sulit dibandingkan bahasa yang lainnya (bahasa Indonesia dan Arab) ; Perpustakaan menyediakan literatur berbahasa Inggris hanya sedikit, tidak seperti penyediaan buku berbahasa Indonesia dan bahasa Arab.

Sedangkan bahasa lain tidak muncul dalam penyusunan skripsi oleh mahasiswa IAIN Sunan Kalijaga Yogyakarta, hal ini kemungkinan disebabkan karena memang literatur berbahasa lain tidak dipergunakan dalam penyusunan skripsi tersebut atau memang terlalu sulit untuk menterjemahkan ke dalam bahasa Indonesia walaupun UPT Perpustakaan juga menyediakan literatur berbahasa lain sebesar $7 \%$ judul dan $4 \%$ eksemplar.

\section{Hasil analisis keterpakaian koleksi UPT Perpustakaan}


Dari hasil analisis 11058 sitasi yang ada untuk seluruh koleksi skripsi tahun 2000 di UPT Perpustakaan IAIN Sunan Kalijaga Yogyakarta didapatkan hasil bahwa judul koleksi yang banyak disitir oleh mahasiswa dalam penyusunan skripsinya adalah sangat merata dan sangat bervariasi, dari mulai frekuensinya 196, sampai dengan yang frekuensinya 1 kali sitiran. Kemudian dapat disimpulkan bahwa UPT Perpustakaan IAIN Sunan Kalijaga Yogyakarta mempunyai buku yang beragam yang dapat dimanfaatkan.

Subjek yang paling banyak disitir adalah Qur'an dan fikih dan sepuluh besar yang menempati peringkat pertama judul buku yang digunakan adalah $A l$ Qur'an dan terjemahnya, menempati peringkat pertama dengan memperoleh 196 sitiran, (1.8\%), yang ke dua adalah dengan judul Metodologi Research memperoleh 112 sitiran, (1,0\%) dan yang ke tiga adalah Ushul al Fiqh, mendapat 81 sitiran, $(0.7 \%)$ dari total prosentase yang ada, ke empat Figh as Sunnah sebanyak 76 sitiran (0.7\%), ke lima Shahih Abi Abdillah al Bukhary bi Syarh al Kirmany, sebanyak 73 sitiran, ke enam Kamus Umum Bahasa Indonesia sebanyak 71 sitiran, $0.7 \%$ dari total keseluruhan. Peringkat ke tujuh adalah Prosedur Penelitian : Suatu Pendekatan Praktis, sebanyak 64 sitiran, Sahih al Muslim 64 sitiran, masing-masing juga sebesar $0.6 \%$. Peringkat ke delapan adalah Kamus Besar Bahasa Indonesia 59 sitiran dan yang peringkat ke sembilan Ilmu Pendidikan Islam sebanyak 55 sitiran, yang menunjukkan $0.5 \%$ dan yang ke sepuluh adalah Sunan $A b i$ Daud sebanyak 54 sitiran, $0.5 \%$. Sedangkan sebagian besar adalah judul-judul koleksi yang sedikit sekali disitir, bahkan yang disitir satu kali sangat banyak, yang kemudian kalau kita jumlah keseluruhannya mencapai 4705 sitiran, $42.5 \%$. Tetapi jumlah ini tidak bisa dikatakan jumlah yang mewakili jumlah terbesar, karena jumlah tersebut hanya akumulasi dari literatur yang disitir satu kali saja.

\section{Hasil analisis ketersediaan koleksi UPT Perpustakaan}

Ketersediaan koleksi dapat terlihat pada hasil sebaran berdasarkan jenis literatur yang menghasilkan buku memperoleh frekuensi 10133 (92\%) dan majalah, jurnal, surat kabar mendapatkan frekuensi 925 (8\%) sitiran, yang kemudian ditetapkan menjadi 'core journal' sebanyak 13 judul jurnal. Sedangkan untuk majalah populernya, yang mendapatkan sitiran lebih dari satu adalah Tempo ( 18 sitiran), Suara Muhammadiyah (15 sitiran), Gatra (4 sitiran) dan Himmah (3 sitiran). Untuk surat kabarnya adalah Republika yang menempati peringkat pertama (225 sitiran).

Dari hasil sebaran 10 besar judul yang disitir mahasiswa, bila kita bandingkan dengan koleksi yang ada di UPT Perpustakaan IAIN Sunan Kalijaga Yogyakarta menunjukkan bahwa sebagian besar koleksi yang digunakan mahasiswa dalam menyusun skripsinya tersebut tersedia di Perpustakaan, sebanyak 99,98\%.

Kenyataan tersebut juga didukung dengan kondisi riil yang ada di Perpustakaan IAIN Sunan Kalijaga Yogyakarta bahwa koleksi yang banyak disajikan adalah koleksi jenis buku dengan prosentase dalam judul sebesar $81 \%$ dan dalam eksemplar sebesar $85 \%$, sedangkan koleksi majalah, jurnal, surat kabar mempunyai prosentase dalam judul sebesar $19 \%$ dan dalam eksemplar sebesar $15 \%$.

Hasil analisis ketersediaan ini menunjukkan bahwa perpustakaan mempunyai koleksi yang sangat beragam yang dapat dimanfaatkan oleh pengguna perpustakaan. Disamping itu juga terlihat bahwa pada pembahasan sebelumnya, UPT Perpustakaan mempunyai koleksi buku dan majalah, jurnal, surat kabar, dengan rasio buku sebesar $81 \%$ dan dalam eksemplar sebesar $85 \%$ dan majalah, jurnal, surat kabar mempunyai prosentase dalam judul sebesar $19 \%$ dan dalam eksemplar sebesar $15 \%$, dengan sebaran subjek dokumen beragam.

Sedangkan koleksi yang berupa majalah, jurnal, surat kabar, UPT Perpustakaan IAIN Sunan Kalijaga Yogyakarta 
yang mempunyai prosentase dalam judul sebesar $19 \%$ dan dalam eksemplar sebesar $15 \%$.

UPT Perpustakaan telah menyediakan koleksi majalah dan jurnal sebesar 19\%, walaupun dari segi keterpakaiannya, baru dipergunakan sebesar $8 \%$ oleh mahasiswa yang menyelesaikan skripsi di IAIN Sunan Kalijaga Yogyakarta.

Kalau dilihat dari segi perbandingan koleksi buku dengan majalah dan jurnal yang ada, maka prosentase untuk majalah dan jurnal masih sedikit dibandingkan dengan buku. Tetapi dari segi ketersediaan koleksi yang dibandingkan dengan keterpakaiannya, maka UPT Perpustakaan IAIN Sunan Kalijaga Yogyakarta telah menyediakan koleksi majalah, jurnal, surat kabar yang dibutuhkan oleh mahasiswa dalam penulisan skripsinya.

Ditinjau dari segi bahasa, di UPT Perpustakaan IAIN Sunan Kalijaga sendiri juga menyediakan koleksi yang beragam bahasanya, antara lain bahasa Indonesia, bahasa Arab, bahasa Inggris, bahasa Perancis, bahasa Belanda, dan bahasa Jawa. Adapun rasio prosentase koleksi berdasarkan bahasa di UPT Perpustakaan IAIN Sunan Kalijaga Yogyakarta adalah sebagai berikut : bahasa Indonesia dari segi judulnya sebesar $60 \%$, dari segi eksemplar sebesar $66 \%$. Sedangkan pada peringkat kedua adalah bahasa Arab dari segi eksemplarnya, sebesar $16 \%$, tetapi dari segi judulnya sebesar $14 \%$, menempati urutan ketiga dan urutan yang kedua adalah bahasa Inggris dari segi judul sebesar $19 \%$, dan dari segi eksemplar sebesar $15 \%$ yang menempati urutan ketiga. Sedangkan UPT Perpustakaan juga menyediakan koleksi yang berbahasa lain seperti bahasa Perancis, Belanda, Jawa dan lain-lain, sebesar $7 \%$ (dari segi judul) dan sebesar $3 \%$ (dari segi eksemplarnya). Kenyataan seperti ini menunjukkan bahwa UPT Perpustakaan menyediakan beragam bahasa, tetapi dapat dicatat disini bahwa pada bahasa Arab, yang dari segi eksemplarnya, sebesar $16 \%$, menempati urutan ke dua, tetapi dari segi judulnya sebesar $14 \%$, menempati urutan ketiga. Hal ini berarti bahwa UPT Perpustakaan masih minim judul koleksi berbahasa Arab, tetapi eksemplarnya sudah banyak.

Kesesuaian koleksi yang dibutuhkan, yaitu pada sebaran subjek yang sangat merata antara Qur'an, fikih, pendidikan dan hadis yang kemudian kita crosscheck-kan pada judul-judul skripsi sebagai contoh kesesuaian dengan ketersediaan koleksi yang ada di UPT Perpustakaan, yaitu : Skripsi Edy Hartono Tarbiyah PAI 94412847 dengan judul skripsi 'Prinsip-prinsip pendidikan akhlak dalam al Qur'an surat al hujurat 1-18" yang didalamnya memuat 15 judul buku yang benar-benar dituliskan dalam catatan kaki dan sesuai subjek, sementara majalah, jurnal lebih sedikit digunakan. Antara lain di dalamnya terdapat koleksi yang berjudul Ilmu pendidikan Islam, Al Qur'an dan terjemahannya, Psikologi pendidikan yang sesuai dengan pokok bahasan skripsi tersebut. Dan literatur yang disitir itu memiliki kaitan dengan isi skripsi yang menyitir dan tersedianya koleksi di UPT Perpustakaan. Dan dari keseluruhan data yang disitir oleh mahasiswa, diperoleh hasil sebagai berikut : Jumlah koleksi yang dipakai untuk menulis skripsi adalah 4661 judul yang menghasilkan sebanyak 11058 sitiran ; Dari 798 judul koleksi yang diambil sampai pada frekuensi atas akhir 2, tersedia di UPT Perpustakaan IAIN Sunan Kalijaga Yogyakarta sebanyak 99,98 \% ; Koleksi yang tidak tersedia di UPT Perpustakaan sebanyak 15 judul.

\section{PENUTUP/KESIMPULAN}

1. Dari pola penggunaan literatur dalam skripsi berdasarkan jenis literatur yang disitir, didapatkan hasil bahwa buku adalah jenis literatur yang paling banyak disitir, mencapai 10133 kali disitir (92\%), berdasarkan bahasa yang disitir, bahasa Indonesia mendapatkan sitiran yang terbanyak, sebanyak 8420 sitiran (77\%) dan judul literatur yang digunakan, dari hasil analisis 11.058 sitiran yang ada untuk 
seluruh koleksi skripsi, ternyata judul yang disitir mahasiswa sangat merata dan bervariasi, dari mulai frekuensi sitiran sebanyak 196 (1,8\%), sampai pada frekuensi 1 kali sitiran.

2. Keterpakaian koleksi di UPT Perpustakaan IAIN Sunan Kalijaga Yogyakarta sesuai dengan hasil sebaran koleksi yang merata, dengan prosentase $1.8 \%$ (196 judul), $1.0 \%$ (112 judul), $0.7 \%$ (230 judul), $0.6 \%$ (199 judul), $0.5 \%$ (20 judul), $0.4 \%$ ( 317 judul), $0.3 \%$ (133 judul) serta $0.2 \%$ (499 judul), sampai pada $0.0 \%$ yang jumlahnya sangat banyak. Artinya bahwa $99.98 \%$ koleksi yang ada di UPT Perpustakaan IAIN Sunan Kalijaga dipakai mahasiswa dalam menyelesaikan skripsinya.

3. Ketersediaan koleksi terlihat pada hasil sebaran jenis, bahasa, dan judul yang merata yang kemudian dibandingkan dengan koleksi di UPT Perpustakaan. Hasilnya adalah koleksi berbahasa Indonesia menempati peringkat pertama, kemudian bahasa Arab dan bahasa Inggris, kemudian buku merupakan jenis literatur yang paling banyak digunakan dalam menulis skripsi, disusul majalah, jurnal dll. Dan ketersediaan koleksi menunjukkan $99.98 \%$. Artinya bahwa UPT Perpustakaan menyediakan koleksi sebesar 99.98 \%. Dari keseluruhan koleksi yang dibutuhkan. Hal ini berarti dapat disimpulkan bahwa perpustakaan mempunyai koleksi yang sangat beragam yang dapat dimanfaatkan oleh pengguna perpustakaan. Kemudian ketersediaan koleksi yang ada sudah sesuai dengan kebutuhan penulisan skripsi mahasiswa IAIN Sunan Kalijaga Yogyakarta.

\section{REFERENSI}

Atkinson, R. "Networks, hypertext and academic information services : some longer - range implications". College and Research Libraries (54) : 199 - 215, 1993. dikutip dalam "The Librarian profession and the internet implications and scenarios for change" oleh June Abbas, 1997. abbasjun@esuvm.emporia.edu, school of library and information manajemen Emporia State University.6 April 2001. 13.00 wib.

Carrigan, Dennis. P., 1995. "Toward a theory of collection development", dalam Library Acquisitions : practice and theories, vol.19, no. 1. USA : Pergamon.

Collection assessment. assessment.info@dlapr.lib.az.us.17 Mei 2001. 13.00 wib.

Garvey, William D. 1979. Communication : the essence of science. New York : Pergamon Press.

Jenkins, Clare and Mary Morley. 1992. “Collection” dalam Librarianship and information work world wide 1992 an annual survey. oleh Maurice B. Line ; Graham Machenzie and Ray Prytherch.

Kuronen, Timo and Paivi Pekkarinen. 1999. "Ranganathan revisited : a review article", dalam Jurnal of librarianship and information scinece, 31 (1) Maret 1999.

Lancaster, F.W. If you want to evaluate your library ....1988. Champaign : University of illinois.

Magriil, Rose Mary and John Corbin. 1989. Acquisition management and collection development in libraries. $2^{\text {nd }}$ ed. Chicago : American Library Association.

Nasution, S., 1996. Metode Research : penelitian ilmiah. Jakarta : Bumi Aksara.

Perpusnas RI. 1992. Survai dan kajian perpustakaan perguruan tinggi : kajian pelayanan di 7 propinsi. Jakarta : Perpusnas RI, 1992.

$$
\text { 1999. Pedoman pengelolaan koleksi }
$$
perpustakaan perguruan tinggi. Jakarta : Perpustakaan Nasional RI Bagian Proyek Pengembangan sistem Nasional Perpustakaan.

Prytherch, Ray. 1996. Harrod's librarians'glossary : 9000 terms used in information management, library science, publishing, the book trades and archive management. $8^{\text {th }} \mathrm{ed}$. Inggris : Gover, 1996.

University of wyoming Libraries. 1998. "Collection assessment”. http://www.lib.uwyo.edu. 17 Mei 2001.13.00 wib. Wedgeworth, Robert (ed.).1993. World encyclopedia of library and information services. $3^{\text {rd }}$ ed. Chicago : American Library Association. 